\title{
Post traumatic retroperitoneal fibrosis as a cause of low-back pain
}

\author{
Fibrosis retroperitoneal postraumática \\ como causa de dolor lumbar
}

\author{
A.M. Hidalgo-Ovejero ${ }^{1}$, M. Rivero-Marcotegui ${ }^{3}$, S. García-Mata ${ }^{2}$, \\ G. Jiménez-Lopez de Oñate ${ }^{4}$, M. Montesino-Semper ${ }^{5}$, S. Ostiz-Zubieta ${ }^{4}$
}

\begin{abstract}
We present the case of a male patient with post traumatic retroperitoneal fibrosis whose main clinical expression was low-back pain. Diagnosis was established using CAT-scan and MRI, which revealed a large mass of soft tissue that almost entirely enveloped the abdominal aorta. Treatment with $40 \mathrm{mg}$ of prednisone every 24 hours was established. This dose was reduced gradually, and progressive remission of clinical signs and symptoms was achieved, with a significant improvement of subsequent imaging-test results. Treatment was continued for one year. Two and a half years later the patient remains symptom-free, with no recurrence of his condition.
\end{abstract}

Key words. Retroperitoneal fibrosis. Low-back pain. Trauma. Glucocorticoids.

\section{RESUMEN}

Se presenta el caso de un paciente varón afecto de una fibrosis retroperitoneal postraumática, a cuyo diagnóstico se llegó a partir de dolor lumbar como síntoma principal. El diagnóstico se efectuó en base a los estudios mediante CT y RM, los cuales demostraron una gran masa de tejido de partes blandas que rodeaban la aorta. El tratamiento consistió en dosis de prednisona que inicialmente se instauró a $40 \mathrm{mg}$ cada 24 horas y posteriormente se fue reduciendo de forma gradual hasta la remisión de los signos y síntomas, y consecuentemente de los estudios de imagen. El tratamiento con corticoides se mantuvo durante un año. Dos años y medio el paciente está libre de síntomas sin recidiva de su proceso.

Palabras clave. Fibrosis retroperitoneal. Lumbalgia. Trauma. Glucocorticoides.
1. Head of Spine Unit. Professor of Surgery Area.

Public University of Navarre.

2. Spine Unit

3. Unit of Internal Medicine.

4. Radiology Department.

5. Urology Department Central Hospital of Navarre

Recepción: 22 de enero de 2011

Aceptación provisional: 9 de marzo de 2011

Aceptación definitiva: 11 de julio de 2011

\section{Correspondence to:}

Servicio de Traumatología

Complejo Hospitalario de Navarra

C/Irunlarrea, 3

31008 Pamplona

Spain

E-mail: angelhidalgo@ya.com 


\section{INTRODUCTION}

Retroperitoneal fibrosis is a fibrotic inflammatory process involving the periaortic retroperitoneal tissues, that compresses the adjacent, mainly genitourinary, structures.

Its true prevalence is unknown, but an estimated 1,3 per 100,000 inhabitants are affected by it each year. It is more frequent in males, and usually develops between the ages of 50 and 60 . About two thirds of cases are idiopathic; in the remaining one third of the population, the condition is associated with other pathologies. In its idiopathic form, the condition is generally called Ormond's disease, after one of the authors by whom it was first described ${ }^{1}$.

Compression of the retroperitoneal structures causes non-specific low-back pain, which allows for diagnosis of the condition $^{2-5}$. Medullary compression has been described in exceptional cases, as a result of expansion of the fibrosis into the epidural space ${ }^{6}$.

Although retroperitoneal fibrosis has classically been described as secondary to trauma ${ }^{7}$, an extensive review of the literature only revealed four cases associated with severe traumatic episodes, all of which, in themselves, caused major lesions of the urological system ${ }^{8-11}$.

A case of post-traumatic retroperitoneal fibrosis, diagnosed as a result of atypical low-back pain, is presented.

\section{CASE REPORT}

The case is presented of a 52-year-old male with no significant medical history who had been suffering from low-back pain, mainly at night, for one and a half months previously. The pain, which prevented him from sleeping, partially responded to anaelgesics and non-steroid anti-inflammatories. Three weeks before the onset of symptoms, the patient had suffered lateral dorsolumbar trauma on his right side, with extensive associated bruising. Although the affected area was painful, no back-pain was initially present. External signs of bruising were no longer visible at the time of consultation.

The patient reported slight asthenia and a weight-loss of $4 \mathrm{~kg}$ in the previous month. Clinical examination revealed no abnormal results, and no neurological deficit was found. Palpation of the right paravertebral dorsolumbar region produced slight pain. X-rays were normal, with no lesions present.

As clinical signs and symptoms persisted, full blood tests were performed, revealing no significant result other than an ESR of 90 .

These tests were followed up with a technetium-scintigraphy scan showing increased uptake at the level of $\mathrm{T} 11$, on the right side, and on the right kidney (Fig. 1)

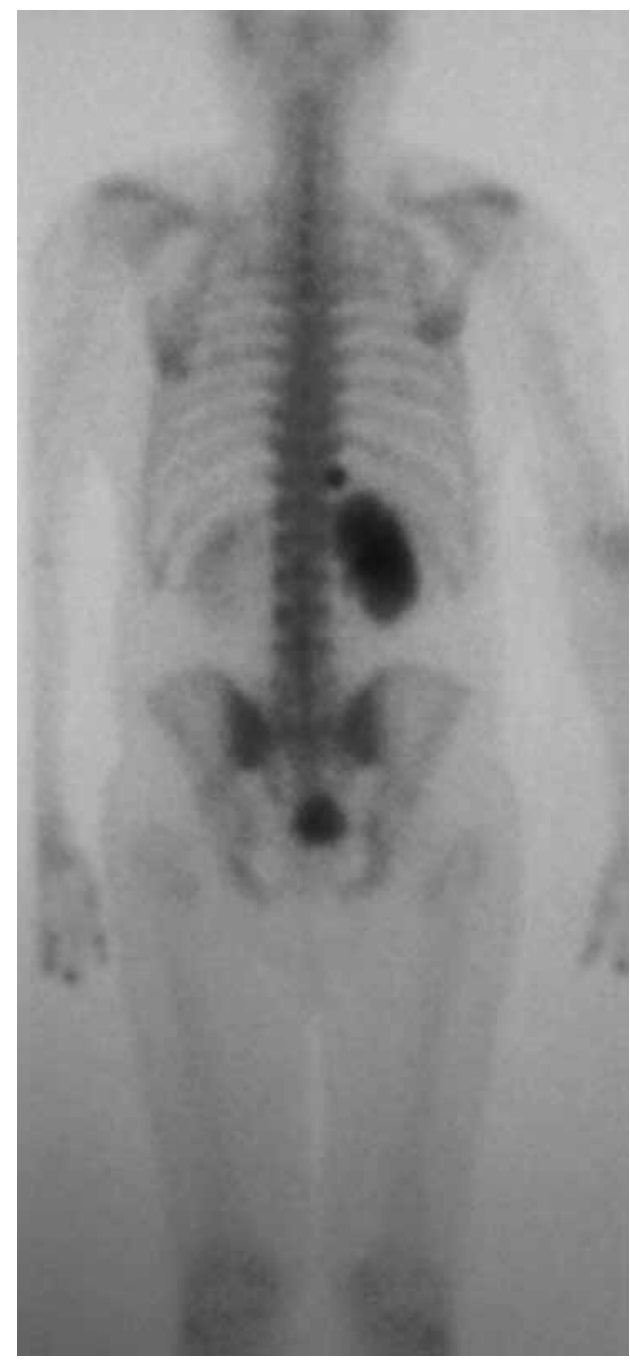

Figure 1. Technetium scintigraphy shows an increased level of activity in the region of the right kidney and over the right side of T11.

Since a vertebral tumour was suspected, a CAT-scan and a subsequent MRI were perfor- 
med. These revealed hydronephrosis on the right side, as well as a mass of soft tissue around the aorta, extending from the renal hilum for 15 cm distally, and slight but consistent gadolinium uptake (Figs. 2A, 2B). The described findings were compatible with retroperitoneal fibrosis. A fracture of the head of the eleventh rib was also found, at the level of the costovertebral joint (Fig. 3), which would explain the increased scintigraphic uptake in the vertebral region.

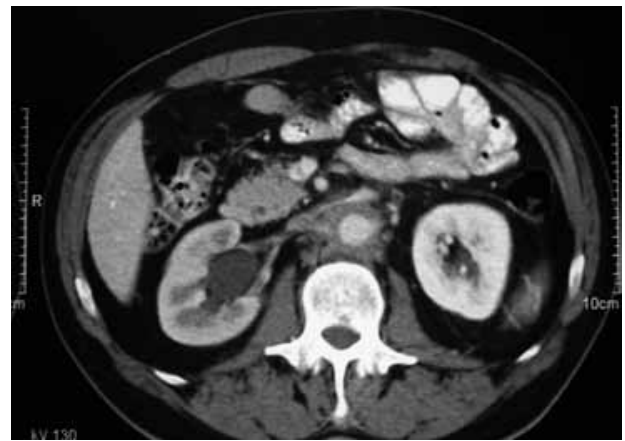

A

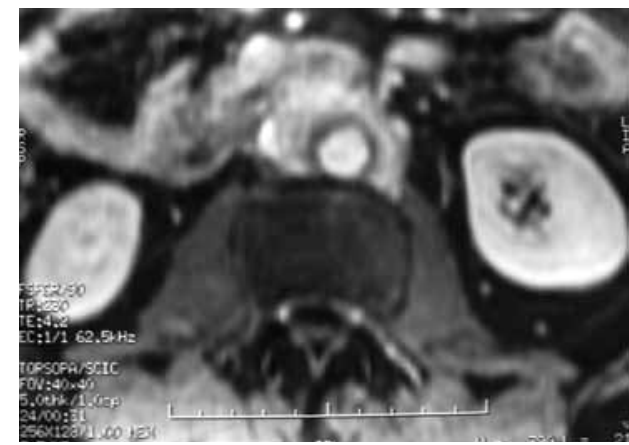

B

Figure 2. A) Contrast CT scan and B) Gadolinium MRI images revealing hydronephrosis of the right kidney, and a soft-tissue mass that descends from the renal hilum, down the abdominal aorta, to the bifurcation of the iliac arteries.

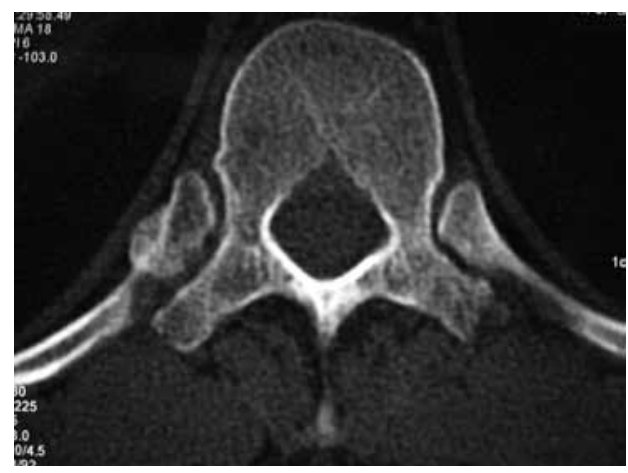

Figure 3. CT-scan image showing the fractured rib at the level of the right side of T11.

Treatment with corticosteroids was begun, starting with $40 \mathrm{mg} / 24$ hours for six weeks. The dose was gradually reduced to $10 \mathrm{mg} / 24$ hours, and then maintained at that level for one year. A marked improvement of the patient's clinical signs and symptoms was noted immediately after commencing treatment.

Revision CAT-scans showed a significant reduction of the retroperitoneal mass, and a decrease in size of the right kidney (Fig. 4).

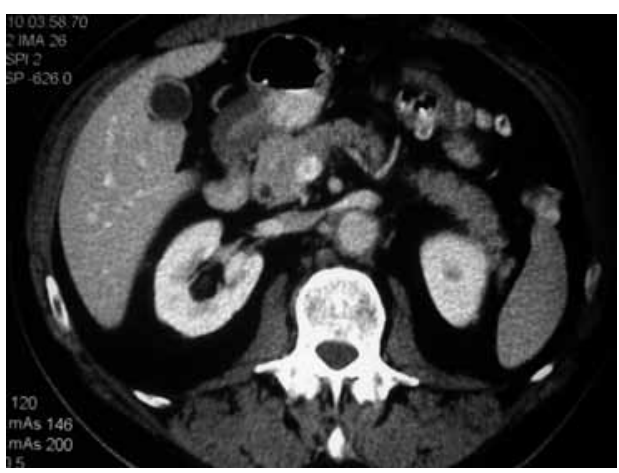

Figure 4. Contrast CT-scan showing the decrease and disappearance of the periaortic soft-tissue mass, 2 years after the onset of the symptoms.

Three years later, the patient remains symptom-free.

\section{DISCUSSION}

As previously mentioned, the most frequent cause of retroperitoneal fibrosis is idiopathic. However, other pathologies must be ruled out before reaching that diag- 
nosis ${ }^{7}$.These include certain autoimmune and rheumatic diseases; perianeurysmal retroperitoneal fibrosis and inflammatory abdominal aortic aneurysms ${ }^{12}$; medications including, among others, ergot alkaloids, tramadol and paracetamol; metastases; sarcoidosis; urological tumours; radiotherapy; intestinal perforation following abdominal barium-meal examinations ${ }^{13}$; trauma or haematoma; surgical injuries; and inflammations and infections, of whatever kind, of the retroperitoneal space.

Some authors have recently reported an association between Peyronie's disease and retroperitoneal fibrosis ${ }^{14}$.

In our case, we believe that the probable cause of retroperitoneal fibrosis was our patient's previous history of trauma and haematoma.

The fact that the patient was suffering from intense, predominantly nocturnal pain, together with the normal x-rays and an increased uptake at the level of the vertebral region, led us to consider a tumour as the most probable diagnosis. However, CAT-scan revealed that the increased uptake was due to the fractured rib.

Symptoms of retroperitoneal fibrosis are associated with entrapment and compression of the adjacent urinary structures (ureter, kidney) ${ }^{15}$, the intestines ${ }^{16}$, the vascular structures (aorta, vena cava, iliac veins $)^{17}$, and the neurological structures (compression of the plexus, or even the medulla ${ }^{6,18}$. Clinical presentation may therefore vary widely, with symptoms ranging from oligoanuria to high blood pressure ${ }^{19}$ and neurological or vascular disorders.

The diagnostic imaging is usually done by CT-scan or MRI, although recently some originals have been published referring to the use of 18-F-fluorodeoxyglucose (FDG) positron emission tomography (PET) for both the diagnosis ${ }^{20}$ and assessment of the evolution of the disease ${ }^{21}$, although its use is not standardized at present.

Diagnosis is confirmed definitely by means of a biopsy. However, in some instances, when the results of the currently available imaging tests are highly characteristic, biopsy may not be needed. This is mainly the case when clinical data, test re- sults and other examinations all point to an exclusively idiopathic aetiology, or when it is believed that the condition is secondary to a disease that has already been determined $^{22}$.

Some degree of consensus exists as to the initial treatment of idiopathic cases with corticosteroids ${ }^{23}$, although these have shown no clear evidence of potential benefits $^{24}$. New therapies are also emerging, including the use of immunosuppressors ${ }^{25}$ or mycophenolate mofetil, which can improve the effect of corticosteroids when used in combination with the latter ${ }^{26}$. In our case, these therapies were used with good results. Treatment with corticosteroids should last for about one year, since recurrence of the disease is frequent after discontinuing therapy; long-term results, however, are generally good ${ }^{23}$. Although there are in literature different doses of corticosteroids, we opted for a relatively low dose but maintained over time (one year), assessing the possibility of raising the dose if the response, was not satisfactory. Progress is controlled by serial assessment of analytical parameters, mainly the ESR and C-reactive protein values, and the reduction of the soft-tissue mass is monitored using CAT-scan, MRI or PET.

Depending on the results of treatment, and on the degree and extent of compression, especially in the urological region, surgical release of the ureters or other involved structures may be necessary, and can be performed by means of an open or laparoscopic approach ${ }^{27}$, or by placing stents ${ }^{28}$, with a view to achieving permeability of the urinary system.

\section{REFERENCES}

1. van Bommel EF, Jansen I, Hendriksz TR, AARnOUdSE AL. Idiopathic retroperitoneal fibrosis: prospective evaluation of incidence and clinicoradiologic presentation. Medicine (Baltimore) 2009; 88: 193-201.

2. Onuigbo M, Lawrence K, Park S. Retroperitoneal fibrosis: unusual cause of low back pain. South Med J 2001; 94: 735-737.

3. Nemec P, Rybnickova S, Fabian P, Fojtik Z, SouCEK M. Idiopathic retroperitoneal fibrosis: an 
unusual cause of low back pain. Clin Rheumatol 2008; 27: 381-384.

4. Blanc G, Girard N, Alexandre C, Vignon E. Retroperitoneal fibrosis: a rare vascular and immune entity disclosed by chronic lombalgia. Joint Bone Spine 2007; 74: 497-499.

5. Owens D, Johnston D, Barua J, Wicks S, ChakraVARTY K. An unusual cause of back pain. J Clin Rheumatol 2006; 12: 41-42.

6. Dorado-Bouix L, Millan-Torne M, CapelladesFont J, Goma-Gallego M, Olive A. Sindrome de compresion medular: una rara forma de presentación de la fibrosis retroperitoneal. Rev Neurol 2004; 39: 1143-1145.

7. van Bommel EF. Retroperitoneal fibrosis. Neth J Med 2002; 60: 231-242.

8. Sarramon JP, Durand D, Lazorthes F, That HT, Suc JM. [An accident related to a seat belt. Lymphocoele and extrinsic stenosis of the ureter in a transplant patient. Reparative surgery (author's transl)]. J Urol Nephrol (Paris) 1976; 82: 601-605.

9. Martínez Bengoechea J, Mínguez Pemán J, Allepuz Losa C, González Enguita C, Rioja Sanz C, Rioja SANZ LA. Fibrosis retroperitoneal por hematoma perirrenal extenso. Arch Esp Urol 1990; 43: 1007-1009.

10. Rao MS, Bapna BC, Vaidyanathan S. Ureteral and periureteral fibrosis as delayed sequelae to lower urinary tract injury. J Urol 1975; 113 : 610-613.

11. AmIs ES, JR. Retroperitoneal fibrosis. AJR Am J Roentgenol 1991; 157: 321-329.

12. Vaglio A, Palmisano A, Ferretti S, Alberici F, Casazza I, Salvarani C et al. Peripheral inflammatory arthritis in patients with chronic periaortitis: report of five cases and review of the literature. Rheumatology (Oxford) 2008; 47: $315-318$.

13. CoRdone RP, Brandeis SZ, Richman H. Rectal perforation during barium enema. Report of a case. Dis Colon Rectum 1988; 31: 563-569.

14. Akbal C, Tanidir Y, Ozgen MB, Simsek F. Erectile dysfunction and Peyronie's disease in patient with retroperitoenal fibrosis. Int Urol Nephrol 2008; 40: 971-975.

15. ChIN GK, McGonigle RJ. Non-surgical cause of hydronephrosis: retroperitoneal fibrosis. Intern Med J 2007; 37: 136-137.

16. Martins PN, Glanemann M, Koelble K, WeideMANN H, Neuhaus P. Ileus due to severe aggravation of retroperitoneal fibrosis after sigmoidectomy. Int J Colorectal Dis 2008; 23: 217-218.
17. Houle BJ, Ellwood RA. Retroperitoneal fibrosis from aortic aneurysm causing vena cava obstruction: a case report. Angiology 1982; 33: 64-66.

18. de Sa J, Pimentel J, Carvalho M, Evangelista P, MarTins P. Spinal cord compression secondary to idiopathic retroperitoneal fibrosis. Neurosurgery 1990; 26: 678-681.

19. DAS D, BRIGG J, BRown CM. Hypertensive encephalopathy in a patient with retroperitoneal fibrosis. Postgrad Med J 1999; 75: 730731.

20. Young PM, Peterson JJ, Calamia KT. Hypermetabolic activity in patients with active retroperitoneal fibrosis on F-18 FDG PET: report of three cases. Ann Nucl Med 2008; 22: 87-92.

21. Jansen I, Hendriksz TR, Han SH, Huiskes AW, van Bommel EF. (18)F-fluorodeoxyglucose position emission tomography (FDG-PET) for monitoring disease activity and treatment response in idiopathic retroperitoneal fibrosis. Eur J Intern Med 2010; 21: 216-221.

22. Geoghegan T, Byrne AT, Benfayed W, McAuley $\mathrm{G}$, ToRreggiani WC. Imaging and intervention of retroperitoneal fibrosis. Australas Radiol 2007; 51: 26-34.

23. van Bommel EF, Siemes C, HaK LE, van der Veer SJ, HENDRIKSZ TR. Long-term renal and patient outcome in idiopathic retroperitoneal fibrosis treated with prednisone. Am J Kidney Dis 2007; 49: 615-625.

24. Maillart E, Laueriere L, Kassis S, MoulonguetDoleris L, Prinseau J, Baglin A et al. [Is there an evidence-based management of idiopathic retroperitoneal fibrosis?]. Rev Med Interne 2006; 27: 854-857.

25. Vaglio A, Palmisano A, Corradi D, Salvarani C, Buzio C. Retroperitoneal fibrosis: evolving concepts. Rheum Dis Clin North Am 2007; 33: 803-817, vi-vii.

26. Swartz RD, LaKe AM, Roberts WW, Faerber GJ, JR JS. Idiopathic retroperitoneal fibrosis: a role for mycophenolate mofetil. Clin Nephrol 2008; 69: 260-268.

27. Srinivasan AK, Richstone L, Permpongkosol S, Kavoussi LR. Comparison of laparoscopic with open approach for ureterolysis in patients with retroperitoneal fibrosis. J Urol 2008; 179:1875-1878.

28. Fry AC, Singh S, Gunda SS, Boustead GB, HanBURY DC, McNicholas TA et al. Successful use of steroids and ureteric stents in 24 patients with idiopathic retroperitoneal fibrosis: a retrospective study. Nephron Clin Pract 2008; 108: c213-220. 